\title{
PENDAYAG UNAAN NASKAH AKADE MIK DALAM PEMBENTUKAN PERATURAN DAERAH KABUPATEN/KOTA (Suatu Kajian Terhadap Kebijakan Pemerintah Daerah Dan DPRD Kabupaten Mempawah, Kabupaten Kubu Raya Dan Kota Pontianak Provinsi Kalimantan Barat).
}

\author{
M Fahmi Hazdan \\ Email :famihazdan@gmail.com \\ Mahas iswa Program Magister Ilmu Hukum, Program Pascasarjana \\ Fakultas Hukum Universitas Sebelas Maret Surakarta \\ Adi Sulistiyono \\ Email :adi_sumo@yahoo.co.id \\ Dosen Fakultas Hukum Üniversitas Sebelas Maret Surakarta
}

\begin{abstract}
This article examines about what are the factors that constrain the inclusion of academic paper in the formation of regional regulations design of Mempawah District, Kubu Raya District, and P ontianak City in West Kalimantan Province in years of 2011, 2012, 2013, 2014, and 2015. And analyze the implications of legislation that does not utilize the academic paper. This article is a non-doctrinal research, and a qualitative descriptive research. Data in this article is derived from in-depth interviews and documentation study. From this research showed the factors that constrain the inclusion of academic paper in the formation of regional regulations design of Mempawah District, Kubu Raya District, and Pontianak City in West Kalimantan in years 2011, 2012, 2013, 2014, and 2015 among others are due to the inclusion of academic paper are not required in the preparation of a formation of regional regulations design in legislation Number 12 Year 2011 about legal drafting. Holders authority of the regulations that do not all have a background in law, especially regarding the establishment of the regulation also be a factor in addition to the lack of awareness of the local community in terms of participation in the process of formation of the regional regulation.
\end{abstract}

Keyword : Academic Paper, Local Regulations, Local Government.

\begin{abstract}
Abstrak
Artikel ini mengkaji tentang apa saja faktor-faktor yang menjadi kendala penyertaan naskah akademik dalam pembentukan Rancangan Peraturan Daerah Kabupaten Mempawah, Kabupaten Kubu Raya dan Kota Pontianak di Provinsi Kalimantan Barat Tahun 2011, 2012, 2013, 2014 dan tahun 2015. Serta melakukan analisis mengenai implikasi Perda yang tidak mendayagunakan naskah akademik tersebut. Artikel ini merupakan sebuah penelitian hukum non-doktrinal, dan merupakan penelitian yang bersifat deskriptif kualitatif.Data dalam artikel ini menggunakan data yang berasal dari hasil wawancara mendalam dan studi dokumentasi. Dari penelitian ini diperoleh hasil bahwa faktor-faktor yang menjadi kendala penyertaan naskah akademik dalam pembentukan Rancangan Peraturan Daerah Kabupaten Mempawah, Kabupaten Kubu RayaDan Kota Pontianak di Provinsi Kalimantan BaratTahun 2011, 2012, 2013, 2014 dan tahun 2015 antara lain ialah karena tidak diharuskannya penyertaan naskah akademik dalam penyusunan suatu Rancangan Peraturan Daerah di dalam Undang - Undang Nomor 12 Tahun 2011 tentang Pembentukan Peraturan Perundang - Undangan. Pemegang wewenang dari pembentuk peraturan yang tidak semua memiliki latar belakang hukum khususnya mengenai pembentukan peraturan perundang - undangan juga menjadi salah satu faktor penyebab selain kurangnya kesadaran dari masyarakat di daerah dalam hal partisipasi dalam proses pembentukan Perda tersebut.
\end{abstract}

Kata kunci : Naskah Akademik, Peraturan Daerah, Pemerintah Daerah. 


\section{A. Pendahuluan}

Penyelenggaraan pemerintahan suatu Negara akan berjalan dengan baik jika lembaga - lembaga negara yang ada di dalamnya memiliki hubungan yang saling mendukung satu dengan lainnya sebagai satu kesatuan serta berjalan sesuai dengan kedudukan, peran, kewenangan dan tanggung jawabnya masingmasing. Indonesia adalah Negara yang wilayahnya terbagi atas daerah - daerah provinsi. Daerah provinsi itu kemudian dibagi lagi menjadi daerah kabupaten dan kota. Setiap daerah mempunyai pemerintahan daerah yang diatur dengan undangundang. Pembagian kekuasaan Negara tersebut bertujuan agar kekuasaan tidak bertumpuk pada satu badan saja, yaitu pemerintah pusat.

Setelah diadakan amandemen terhadap Undang-Undang Dasar Republik Indonesia Tahun 1945 (UUD 1945) telah terjadi banyak perubahan dalam sistem ketatanegaraan dan penyelenggaraan pemerintahan negara R epublik Indonesia.Menurut amandemen terakhir, salah satu pasal dalam UUD 1945 yang diamendemen adalah ketentuan yang terkait dengan P emerintah Daerah sebagaimana termuat dalam Pasal 18 UUD 1945.

Pasal 18 UUD 1945 menyatakan :

1. Negara Kesatuan Republik Indonesia dibagi atas daerah-daerah provinsi dan daerah provinsi itu dibagi atas kabupaten dan kota, yang tiap-tiap provinsi, kabupaten, dan kota itu mempunyai pemerintahan daerah, yang diatur dengan undang-undang.

2. Pemerintahan daerah provinsi, daerah kabupaten, dan kota mengatur dan mengurus sendiri urusan pemerintahan menurut asas otonomi dan tugas pembantuan.

3. Pemerintahan daerah provinsi, daerah kabupaten, dan kota memiliki Dewan Perwakilan Rakyat Daerah yang anggotaanggotanya dipilih melalui pemilihan umum.

4. Gubernur, Bupati dan Walikota masingmasing sebagai Kepala

Pemerintah Daerah Provinsi, Kabupaten dan Kota dipilih secara demokratis.

5. Pemerintah daerah menjalankan otonomi seluas-luasnya, kecuali urusan pemerintahan yang oleh undang-undang ditentukan sebagai urusan Pemerintah Pusat.

6. Pemerintahan daerah berhak menetapkan peraturan daerah dan peraturan-peraturan lain untuk melaksanakan otonomi dan tugas pembantuan.
7. Susunan dan tata cara penyelenggaraan pemerintahan daerah diatur dalam undangundang.

Perubahan dalam sistem penyelenggaran pemerintahan daerahberupa pemberian kewenangan yang luas kepada pemerintah provinsi dan kabupaten/kota untuk mengatur dan mengurus sendiri urusan pemerintahan menurut asas otonomi daerahdan tugas pembantuan, diatur dalam Pasal 18 ayat (2) UUD 1945. Dari ketentuan Pasal 18 ayat (2) UUD 1945 amandemen tersebut, lahirlah potret baru wajah pemerintahan daerah berupa penguatan sistem desentralisasi,sebagaimana diatur dalam Undang-Undang Nomor 23 Tahun 2014 tentang Pemerintahan Daerah. Dari ketentuanPasal 18 ayat (6) UUD 1945 itu menunjukkan, bahwa kewenangan untuk menyusun peraturan perundang-undangan tidak hanya dimiliki oleh pemerintah pusat, tetapi juga dimiliki oleh pemerintah daerah.

Hakikat dari otonomi daerah adalah kemampuan menyediakan ruang publik yang lebar bagi munculnya partisipasi masyarakat didalamnya, tidak hanya secara pasif dimana partisipasi tersebut ditentukan oleh struktur kekuasaan diatasnya (dan itu bukan lah partisipasi, tetapi mobilisasi), juga secara aktif dimana masyarakat memenuhi sepenuhnya atas kebutuhan kebutuhannya, kemudian memilih, merumuskan dan mengupayakan agar dapat tercapai (Solichin Wahab, 2012: iii). Perdamenjadisalahsatu instrumenyangstrategisuntukmewujudkan tujuandesentralisasi.Sebagai suatu dokumen kebijakan pemerintah daerah, tidak mudah untuk mengetahui bagaimana proses dan prosedur pembentukan Perda, bagaimana memahami isi, tujuan, maksud, latar belakang atau alasan suatu Perda dibentuk. Di sisi lain, belum tentu para pengambil kebijakan dan pelaksananya mengetahui dan mengerti apa yang harus dilakukan agar Perda yang dibentuk dapat diterapkan agar sesuai dengan apa yang telah diharapkan. Oleh karena itu tidak tertutup kemungkinan lahirnya banyak Perda bermasalah.

Hamzah Halim dan Kemal Redindo Syahrul Putera juga menegemukakan, bahwa dalam pembentukan Perda, terdapatsorotan yang tajam dari berbagai pihak, baik itu kaitannya dengan tingkat produktifitasnya (produk pembentukan Perda) maupun menyangkut kualitas dari produk pembentukan Perda yang dihasilkannya (Hamzah Halim dan Kemal Redindo Syahrul Putera, 2013 : vii). Dibidang perundang - undangan, pada saat ini 
terdapat kecenderungan pembentukan peraturan perundang - undangan secara berlebihan tanpa melihat dan memperhatikan arah dan prioritas pembangunan nasional. Hal ini masih ditambah dengan rendahnya kualitas sebagian besar peraturan perundang - undangan baik pusat maupun daerah, yang tercermin pada banyaknya peraturan perundang - undangan yang konflik, multi tafsir, inkonsisten dan tidak operasional, baik yang setingkat maupun dengan peraturan perundang-undangan yang lebih tinggi (M Ilham F Putuhena, 2013 : 387).Di antara Perda-perda yang bermasalah sebagian diantaranya bahkan berakhir pada pembatalan.Pembatalan terhadap Perda - Perda tersebut dilakukan setelah melakukan evaluasi terhadap Perda - Perda yang dianggap bermasalah tersebut.Di tahun 2016 saja, ribuan peraturan daerah (perda) yang selama ini dianggap bermasalah akhirnya dibatalkan. Pencabutan 3.143 perda oleh Menteri Dalam Negeri Tjahjo Kumolo diumumkan Presiden J oko Widodo (J okowi) di Istana Negara (Republika, 215-06-2016).

Mayoritas Perda bermasalah terkait dengan persoalan teknis, seperti judul yang tidak sesuai dengan substansi atau materi Perda. Ada empat indikator penyebab Perda bermasalah, yaitu:

1. Pembentukan Perda tidak berdasarkan pada skala prioritas sesuai dengan perkembangan kebutuhan hukum masyarakat;

2. Adanya disharmoni Perda secara vertikal maupun horizontal dengan peraturan Perundang-undangan lainnya;

3. Pembentukan Perda tidak terkoordinasi, terarah, sistematis, dan terpadu yang disusun oleh DPRD dan Pemerintah Daerah, dan

4. Adanya Perda yang disusun tidak didahului dengan penyertaan naskah akademik.

Lahirnya Perda bermasalah tidak terlepas dari kondisi dimana ketika penyusunan darft Raperda tidak didasarkan pada pemahaman secara komprehensif mengenai latar belakang, alasan, tujuan dan cakupan materi yang diatur dalam P erda tersebut. Dalam penyusunan darft Raperda tidak semuanya dis ertai dengan naskah akademik. Dalam artian bahwa, pendayagunaannaskah akademik dalam Perda Kabupaten/Kota belum dapat selaras dengan arti penting dari naskah akademik dalam penyusunan suatu Perda tersebut.

Untuk dapat membentuk Perda yang sesuai dengan kebutuhan masyarakat di daerah diperlukan suatu penjelasan mengenai latar belakang, alasan, tujuan, dasar keabsahan,standar,metode, tehnik pembentukan Perda dan cakupan materi yang diatur dalam Perda. Penjelasan tersebut berupa suatu dokumen hasil kajian ilmiah yang dituangkan dalam suatu naskah akademik. Adanya naskah akademik dalam pembentukan Raperda merupakan acuan, yang berisikan penjelasan mengapa pembentukan Raperda memerlukan suatu kajian yang mendalam dan komprehensif mengenai teori atau pemikiran ilmiah yang berkaitan dengan materi muatan Raperda yang akan dibentuk.

Menurut UU Nomor 12 Tahun 2011, terdapat beberapa pasal yang mengatur tentang perlunya naskah akademik dalam penyusunan peraturan perundang-undangan. Khusus dalam pembentukan peraturan daerah provinsi dan/atau kabupaten/kota diatur dalam Pasal 56 ayat (2), Pasal 57 dan Pasal 63 UU Nomor 12 Tahun 2011.

Pasal 56 UU Nomor 12 Tahun 2011 Tentang Pembentukan Peraturan Perundang-Undangan menyatakan bahwa :

(1) Rancangan Peraturan Daerah Provinsi dapat berasal dari DPRD Provinsi atau Gubernur.

(2) Rancangan Peraturan Daerah Provinsi sebagaimana dimaksud pada ayat (1) disertai dengan penjelasan atau keterangan dan/atau Naskah Akademik.

(3) Dalam hal Rancangan Peraturan Daerah Provinsi mengenai:

a. Anggaran Pendapatan dan Belanja Daerah Provinsi;

b. pencabutan Peraturan Daerah Provinsi; atau

c. perubahan Peraturan Daerah Provinsi yang hanya terbatas mengubah beberapa materi, disertai dengan keterangan yang memuat pokok pikiran dan materi muatan yang diatur.

Secara redaksional memang bunyi Pasal 56 UU Nomor 12 Tahun 2011 dimaksudkan untuk Rancangan Peraturan Daerah Provinsi, namun ketentuan tersebut juga berlaku untuk Rancangan Peraturan Daerah kabupaten/kota. Pemberlakuan Pasal 56 UU Nomor 12 Tahun 2011 untuk Rancangan Peraturan Daerah kabupaten/kota ditunjuk berdasarkan Pasal 63 UU Nomor 12 Tahun 2011 menyatakan, bahwa "Ketentuan mengenai penyusunan Peraturan Daerah Provinsi sebagaimana dimaksud dalam Pasal 56 sampai dengan Pasal 62 berlaku secara 
mutatis mutandis terhadap penyusunan Peraturan Daerah Kabupaten/Kota".

Penyusunan naskah akademik dalam proses pembentukan Perda bukanlah merupakan keharusan, akan tetapi apabila dilihat dari aspek pendayagunaandan pengaturannya, dapat dimaknai bahwa sebuah naskah akademik sangat dibutuhkan dalam pembentukan atau penyusunan draft Raperda. Dengan demikian keberadaan naskah akademik tidak hanya bersifat formalitas tetapi memiliki keterkaitan dengan perencanaan pembentukan Perda.

Berangkat dari paparan diatas, penulis tertarik untuk menulis mengenai pendayagunaannaskah akademik dalam penyusunan Raperda Kabupaten Mempawah, Kabupaten Kubu Raya dan Kota Pontianakdi P rovinsi Kalimantan Barat .

\section{B. Metode Penelitian}

Metode yang digunakan dalam penelitian ini termasuk jenis penelitian hukum nondoktrinal, sedangkan dilihat dari sifatnya termasuk penelitian yang deskriptif kualitatif. Menurut Soetandyo Wignjosoebroto penelitian non-doktrinal adalah, penelitian atas hukum yang tidak dikonsepsikan dan dikembangkan sebagai rules tetapi sebagai regularities yang terjadi dalam kehidupan sehari-hari atau dalam alam pengalaman. Di sini hukum adalah tingkah laku atau aksi-aksi dan interaksi manusia secara aktual dan potensial akan terpola, sebagai realita sosial yang terjadi dalam alam pengalaman indrawi dan empiris. Hukum disini bukan dikonsepkan sebagai rules tetapi sebagai regularities yang terjadi dalam kehidupan sehari-hari atau dalam alam pengalaman. Di mana hukum adalah tingkah laku atau aksi-aksi dan interaksi manusia secara aktual dan potensial akan terpola (Soetandyo Wignjosoebroto, 1974 : 147).

Dalam hubungannya dengan penelitian hukum sosiologis (non-dokrinal) tersebut, maka dalam penelitian ini akan diumpulkan data seteliti mungkin dengan mendeskripsikan proses pembentukan Perda Kabupaten Mempawah, Kabupaten Kubu Raya dan Kota Pontianak di Provinsi Kalimantan Barat pada tahun 2011, 2012, 2013, 2014 dan tahun 2015 yang tidak semuanya disertakan dengan naskah akademik. $P$ roses pembentukan Perda yang tidak semuanya disertakan dengan naskah akademik itu terkait dengan tingkah laku atau aksi-aksi dan interaksi yang terjadi antara pembentuk Perda (P emerintah Daerah dan DPRD Kabupaten Mempawah,
Kabupaten Kubu Raya dan Kota Pontianak) sebagai realita sosial yang terjadi dalam alam pengalaman indrawi dan empiris.

\section{Hasil Penelitian dan Pembahasan}

1. Faktor Penyebab Tidak Disertakannya Naskah Akademik Dalam Penyusunan Rancangan Peraturan Daerah Kota Pontianak, Kabupaten Mempawah dan Kabupaten Kuburaya.

S ebagaimana telah dikemukakan dalam uraian terdahulu, bahwa pendayagunaan naskah akademik dalam pembentukan Raperda khususnya di Kota Pontianak, Kabupaten Mempawah dan Kabupaten Kubu Raya sebenarnya sangat strategis dan merupakan kebutuhan yang tidak dapat dihindarkan apabila akan membentuk Raperda yang baik. Akan tetapi suatu fakta yang tidak da pat diingkari, bahwa Rancangan Peraturan Daerah Kota Pontianak, Kabupaten Mempawah dan Kabupaten Kubu Raya yang dimuat dalam Prolegda Tahun 2011, 2012, 2013, 2014 dan 2015 belum semuanya disertai dengan naskah akademik.

Peraturan daerah merupakan salah satu ciri daerah yang mempunyai hak mengatur dan mengurus rumah tangganya sendiri (otonom).Urusan rumah tangga daerah berasal dari dua sumber, yakni otonomi dan tugas pembantuan (medebewind). Karena itu peraturan daerah akan terdiri dari peraturan di bidang otonomi dan peraturan daerh di tugas pembantuan. Sehingga dapat dikatakan bahwa peraturan daerah di bidang otonomi adalah peraturan daerah yang bersumber dari atribusi, sementara peraturan daerah di bidang tugas pembantuan adalah peraturan daerah yang bersumber dari kewenangan delegasi (Hamzah Halim dan Kemal Redindo Syahrul Putera, 2013 : 50). Rancangan Peraturan Daerah bisa berasal dari usulan Pemerintah Daerah melalui Kepala Daerah yang kemudian diusulkan kepada DPRD untuk kemudian dilakukan pembahasan, bisa juga Rancangan Peraturan Daerah tersebut berasal dari inisiatif dari DPRD. Sebuah Rancangan Peraturan Daerah, apakah merupakan usulan dari Pemerintah Daerah ataupun inisiatif dari DPRD haruslah mengedepankan kepentingan masyarakat umum dalam pembentukannya.

Dalam hubungannya dengan faktorfaktor penyebab belum disertakannya naskah 
akademik dalam penyusunan Rancangan Peraturan Daerah di Kota Pontianak, Kabupaten Mempawah dan Kabupaten Kubu Raya, peneliti akan mencoba mengkaji dengan menggunakan teori legal system Lawrance $M$. Friedman. Lawrence $M$. Friedman memandang hukum sebagai suatu sistem yang terdiri dari komponen: "(i) struktur hukum (legal structure); (ii) substansi hukum (legal substance); dan (iii) budaya hukum (legal culture) (F riedman M. Lawrence, 1969 : 62)."

\section{a. Subtansi Hukum (Legal Subtance)}

Komponen substansi adalah mencakup segala apa saja yang merupakan keluaran dari suatu sistem hukum. Dalam pengertian ini termasuk norma-norma hukum baik yang berupa peraturan, keputusan-keputusan, doktrindoktrin sejauh semuanya ini digunakan dalam proses yang bersangkutan. Sedangkan substansi dari sistem hukum mencakup di dalamnya peraturan perundang-undangan, baik tertulis maupun tidak tertulis, danputusan pengadilan ( $F$ riedman M. Lawrence, 2002 : 47).Peraturan daerah secara subtansi merupakan bagian dari sistem hukum tata negaralndonesia. Sebuah aturan perundang - undangan khususnya Peraturan Daerah yang baik, selain merupakan produk hasil kerja dari pemerintah juga selayaknya dapat menggambarkan aspirasi dari masyarakat. Seperti yang telah dijelaskan sebelumnya di dalam Undang - Undang Nomor 12 Tahun 2011 tentang Pembentukan Peraturan Perundang Undangan, penyertaan naskah akademik dalam penyusunan Raperda di Indonsia bukanlah suatu keharusan. Akan tetapi di sisi lain, penyertaan naskah akademik dalam penyusunan Raperda memiliki peranan yang penting agar peraturan daerah yang kemudian nantinya akan diterapkan apat sesuai dengan kondisi dan kebutuhan masyarakat.

Menurut Bapak J uli Suryadi B. SH, M.Si, Kepala Bagian Hukum Pemerintah Daerah Kabupaten Mmpawah bahwa dalam penerapannya, ada yang memiliki pandangan bahwa penyertaan naskah akademik dalam penyusunan Raperda hanya akan memperlambat proses penyuasunan dari suatu produk hukum. Ada juga yang memiliki pandangan bahwa secara materi, penyertaan naskah akademik sangatlah membantu dalam proses penyusunan suatu produk hukum. Karena dengan adanya naskah akademik kita dapat mengetahui kajian yang lebih dalam dari setiap aspek yang berhubungan dengan penyusunan dari sebuah produk hukum. Hal ini diperlukan untuk menghindari adanya pertentangan, penolakan atau mendapatkan catatan tertentu.Pada ranah penerapannya, menurut Bapak Hudiyanto, SH selaku Kepala Bagian Hukum dan HAM Sekretariat Daerah Kabupaten Kubu Raya di Pemerintahan Daerah Kabupaten Kubu Raya, pada prinsipnya dalam setiap usulan Raperda yang diusulkan oleh pihak eksekutif memang tidak diwajibkan untuk disertakan dengan naskah akademik.Karena memang pada dasarnya pernyetaan naskah akademik dalam penyusunan sebuah Raperda bukanlah suatu kewajiban.

Menurut Bapak Hudiyanto, SH selaku Kepala Bagian Hukum dan HAM Sekretariat Daerah Kabupaten Kubu Raya Pada ranah penerapannya di Pemerintahan Daerah Kabupaten Kubu Raya, pada prinsipnya dalam setiap usulan Raperda yang diusulkan oleh pihak eksekutif memang tidak diwajibkan untuk disertakan dengan naskah akademik. Karena memang pada dasarnya pernyetaan naskah akademik dalam penyusunan sebuah R aperda bukanlah suatu kewajiban.Tidak disertakannya naskah akademik dalam proses penyusunan sebuah Raperda, secara legalitas memang tidak dapat disalahkan. Menurut UU Nomor 12 Tahun 2011, terdapat beberapa pasal yang mengatur tentang perlunya naskah akademik dalam penyusunan peraturan perundang-undangan, akan tetapi hal tersebut tidaklah diharuskan.

Pasal 56 UU Nomor 12 Tahun 2011 Tentang Pembentukan Peraturan Perundang-Undangan menyatakan bahwa :

Rancangan Peraturan Daerah Provinsi dapat berasal dari DPRD P rovinsi atau Gubernur. 
(1) Rancangan Peraturan Daerah Provinsi sebagaimana dimaksud pada ayat (1) disertai dengan penjelasan atau keterangan dan/ atau Naskah Akademik.

(2) Dalam hal Rancangan Peraturan Daerah P rovinsi mengenai:

a. Anggaran Pendapatan dan Belanja Daerah Provinsi;

b. pencabutan Peraturan Daerah Provinsi; atau

c. perubahan Peraturan Daerah Provinsi yang hanya terbatas mengubah beberapa materi, disertai dengan keterangan yang memuat pokok pikiran dan materi muatan yang diatur.

Dari ketentuan di atas dapat diketahui bahwa Rancangan Peraturan Daerah Provinsi dapat diajukan DPRD Provinsi atau Gubernur, dan disertai dengan penjelasan atau keterangan dan/atau Naskah A kademik. Secara redaksional memang bunyi Pasal 56 UU Nomor 12 Tahun 2011 dimaksudkan untuk R ancangan Peraturan Daerah P rovinsi, namun ketentuan ters ebut juga berlaku untuk Rancangan Peraturan Daerah kabupaten/ kota. Pemberlakuan Pasal 56 UU Nomor 12 Tahun 2011 untuk Rancangan Peraturan Daerah kabupaten/kota ditunjuk berdasarkan Pasal 63 UU Nomor 12 Tahun 2011 menyatakan, bahwa "Ketentuan mengenai penyusunan Peraturan Daerah Provinsi sebagaimana dimaksud dalam Pasal 56 sampai dengan Pasal 62 berlaku secara mutatis mutandis terhadap penyusunan Peraturan Daerah Kabupaten/Kota".

Dari kalimat "Rancangan Peraturan Daerah Provinsi sebagaimana dimaksud pada ayat (1) disertai dengan penjelasan atau keterangan dan/atau Naskah Akademik", dapatdigambarkan bahwa penyertaan naskah akademik dalam penyusunan Raperda bukan merupakan suatu keharusan.Frasa "dan/ atau" memberikan pemahaman bahwa naskah akademik di dalam penyusunan sebuah Raperda boleh disertakan dan boleh tidak disertakan.Secara tidak langsung hal tersebut dapat menimbulkan sebuah pola pikir "sesuatu yang tidak diharuskan, mengapa harus dilakukan".Sehingga kemudian dapat menjadi salah satu alasan yang kuat untuk kemudian tidak meyertakan naskah akademik dalam penyusunan sebuah Raperda.
Nasah akademik merupakan bentuk konkrit dari partisipasi masyarakat dalam rangka pembentukan peraturan perundang - undangan (termasuk peraturan daerah yang berbasis riset), hal ini telah memiliki legitimasi dan dasar hukum yang jelas dan konkrit. Out-Put konkrit dari keterlibatan masyarakat adalah sebuah naskah akademik (J azim Hamidi, 2008 : 99). Naskah akademik mengandung uraian yang berisi penjelasan tentang :

a. Perlunya sebuah peraturan harus dibuat;

b. Tujuan dan kegunaan dari peraturan yang akan dibuat;

c. Materi-materi yang harus diatur peraturan tersebut;

d. Aspek-aspek teknis penyusunan.

Jadi, naskah akademik merupakan bagian yang tidak dapat dipisahkan dari penyusunan sebuah rancangan produk hukum (termasuk sebuah rancangan produk hukum daerah (J azim Hamidi, 2008 : 102).

Partisipasi masyarakat di dalam pembentukan Perda tersebut diatur di dalam Undang - Undang Nomor 23 Tahun 2014 Pasal 354 ayat (3) yang mengatur bahwa partisipasi masyarakat penyelenggaraan pemerintahan daerah dalam penyelenggaraan pemerintahan daerah mencakup:

a. Penyusunan Perda dan kebijakan Daerah yang mengatur dan membebani masyarakat;

b. Perencanaan, penganggaran, pelaksanaan, pemonitoran, dan pengevaluasian pembangunan Daerah;

c. Pengelolaan aset dan/atau sumber daya alam Daerah; dan

d. Penyelenggaraan pelayanan publik.

J ika dikaitkan kepada tidak diha ruskannya naskah akademik dalam penyusunan sebuah Perda. Terlihat bahwa seolah - olah kedua aturan tersebut tidak saling mendukung walaupun memiliki prinsip tujuan yang sama. Kedua aturan tersebut sama - sama bertujuan untuk menghasilkan suatu Perda yang baik.

Walaupun seperti itu, ada beberapa daerah yang sudah menyadari tenting arti pentingnya naskah akademik di daam proses penyusunan suatu Raperda. Menurut Ibu Zetmawati SH.,MH, Kepala Bagian Hukum Sekretariat Daerah Kota Pontianak yang 
juga merupakan Kepala Bagian PerundangUndangan dan Humas Sekretariat DPRD Kota Pontianak, di Pemerintahan Daerah Kota P ontianak, penyertaan naskah akademik dalam penyusunan Raperda dapattergantung kepada setiap Raperda yang akan disusun. J ika Raperda tersebut merupakan turunan atau diperintahkan oleh Undang-Undang untuk disusun, maka dalam peyusunan Raperda tersebut tidak disertakan naskah akademik didalamnya. Akan tetapi jika Raperda tersebut merupakan berasal dari Pemerintah Daerah, khususnya usulan dari Eksekutif maka dalam penyusunan Raperda tersbut akan diusahakan untuk disertakan dengan naskah akademik.

Secara legalitas formal, memang bukan menjadi masalah jika sebuah Raperda pada proses penyusunannya tidak menyertakan naskah akademik. Karena hingga saat ini, penyertaan naskah akademik di dalam penyusunan Raperda bukanlah suatu keharusan. Akan tetapi, tidak diharuskannya penyertaan naskah akademik dalam penyusunan suatu Raperda di dalam Undang - Undang Nomor 12 Tahun 2011 dapat menjadi salah satu faktor yang kemudian menyebabkan pemerintah daerah mengambil kesimpulan untuk tidak menyertakannya. Namun, jika dilihat dari sisi legalitas mengenai peran serta masyarakat, maka selayaknya naskah akademik tersebut merupakan salah satu syarat dalam pembentukan sebuah Perda. Karena naskah akademik merupakan wujud nyata dari peran serta masyarakat dalam proses pembentukan Perda tersebut.

\section{b. Struktur hukum (legal structure)}

Struktur dari suatu sistem hukum adalah mencakup berbagai institusi yang diciptakan oleh sistem hukum tersebut. Salah satu di antaranya adalah Pengadilan. Dalam kaitannya dengan ini termasuk pembicaraan tentang bagaimana struktur organisasinya, landasan hukum bekerjanya, pembagian kompetensi dan lain-lain ( $F$ riedman $M$. Lawrence, 2002, 47). Selain itu, bagian dari struktur hukum lainnya ialah pebentuk peraturan perundang-undangan itu sendiri baik itu eks ekutif maupun legislatif.P emegang wewenang pembentuk kebijakan merupakan salah satu bagian dari struktur hukum di dalam tatanan hukum tata negara di Indonesia. Dalam hubungannya dengan penyertaan naskah akademik dalam penyusunan
Raperda, peran dari pemegang wewenang pembentuk kebijakan cukup berpegaruh besar terhadap pendayagunaan dari naskah akademik tersebut di dalam penyusunan Raperda.

Dalam praktik, sering ditemukan bahwa para perancang peraturan perundangundangan pada dinas teknis maupun biro/ bagian hukum Pemerintah Daerah belum mampu menerjemahkan kebijakan pemerintah yang telah disusun kedalam bentuk peraturan daerah yang dapat diterapkan secara efektif. Ketidakmampuan para perancang tersebut disebabkan oleh paling sedikit tiga hal, yaitu (Sony Maulana, 2005 : 4-5):

1. Mitos bahwa perancang tidak menangani urusan kebijakan, sebab yang membuat peraturan daerah adalah para pejabat Pemerintah Daerah dan Dewan Perwakilan Rakyat Daerah, dan bukan perancang;

2. Banyak Daerah yang tidak memiliki aturan mengenai prosedur yang mengharuskan mendasarkan rancangan peraturan daerah pada pemikiran logis berdasarkan fakta di masyarakat;

3. Sangat sedikit dari perancang yang memiliki pemahaman atas teori, metodologi, dan teknik perancangan peraturan perundang-undangan dan yang dapatsecara jelas menerjemahkan kebijakan-kebijakan pemerintah menjadi peraturan daerah yang dapat dilaksanakan secara efektif.

Selain itu, beragamnya latar belakang dari para pemegang wewenang di tingkat legislatif juga berpengaruh terhadap pendayagunaan naskah akademik dalam proses penyusunan Raperda.Tidak semua pemegang wewenang pada tingkat legislatif memiliki latar belakang yang berhubungan dengan bidang hukum, khususnya pembentukan peraturan perundang - undangan. Hal seperti itu seringkali menjadi kendala dalam proses pembentukan suatu Raperda. Di mana terkadang para pemegang wewenang di tingkat legislatif tersebut memiliki pandangan mereka sendiri yang berdasar pada latar belakang mereka tentang apa itu naskah akademik, apa fungsinya dan bagaimana pendayagunaannya di dalam proses penyusunan Raperda.

Berdasarkan hasil wawancara yang telah dilakukan kepada Bapak Hudiyanto, SH selaku 
Kepala Bagian Hukum dan HAM Sekretariat Daerah Kabupaten Kubu Raya dijelaskan bahwa pada pelaksanaannya, pernah terjadi sebuah permasalahan menyangkut dengan naskah akademik penyusunan Raperda. Permasalahan tersebut terjadi pada saat pembahasan tentang Raperda tersebut dengan para anggota DPRD Kabupaten Kubu Raya.Seperti yang kita ketahui, naskah akademik ialah roh dari sebuah Raperda. Suatu dasar yang membangun pasal demi pasal yang ada didalam sebuah Raperda. Akan tetapi, pada pelaksanaannya pada saat pembahasan dari Raperda tersebut, tuangan dari isi Raperda yang sedang dibahas tersebut ternyata tidak mencerminkan apa yang dituliskan didalam naskah akademik. Beberapa dari anggota DPRD Kabupaten tersebut ada yang memiliki pemikiran bahwa Raperda ialah sebuah produk hukum yang dibuat oleh DPRD, oleh karena itu isi dari Raperda tersebut haruslah sesuai dengan pemikiran-pemikiran dari para anggotanya. Walaupun materi-materi tersebut pada dasarnya tidak sesuai dengan apa yang telah disusun didalam naskah akademik. Oleh karena itu naskah akademik tidak harus dijadikan pedoman dalam proses penyusunan Raperda. Karena naskah akademik tersebut merupakan buah pemikiran dari para akademisi, bukan pemikiran dari anggota DPRD itu sendiri.Sehingga pada akhirnya banyak bagian dari Raperda tersebut yang kemudian diubah.

Dari permasalahan tersebut maka patutlah untuk dipertanyakan kembali tentang fungsi dari naskah akademik dalam penyusunan sebuah Raperda tersebut, jika dalam pembahasannya tidak berpedoman kepada naskah akademik yang telah disusun. Dapat kita lihat bahwa ada kemungkinan jika tidak semua anggota dari DPRD Kabupaten Kubu Raya mengetahui dan memahami dengan baik tentang arti dari sebuah naskah akademik dalam penyusunan suatu Raperda. Sehingga beberapa anggota dari DPRD Kubu Raya tersebut tidak menjadikan naskah akademik sebagai acuan dasar pada saat pembahasan sebuah Raperda.

Patut disayangkan jika pada penerapannya masih ada pemegang wewenang perancang peraturan di daerah yang masih belum benar - benar memahami tentang prinsip - prinsip pembentukan peraturan yang baik.khususnya pemahaman tentang pentingnya penyertaan naskah akademik dalam proses penyusunan suatu Raperda. Sehingga pembentukan suatu Perda yang mewakili kebutuhan serta kondisi yang ada di dalam masyarakat menjadi sulit untuk diwujudkan.

\section{c. Budaya hukum (legal culture)}

Budaya hukum oleh Friedman disebut sebagai 'bensinnya motor keadilan', yang selanjutnya dirumuskan sebagai sikap-sikap dan nilai-nilai yang ada hubungan dengan hukum dan sistem hukum, berikut sikap-sikap dan nilai-nilai yang memberikan pengaruh baik positif maupun negatif kepada tingkah laku yang berkaitan dengan hukum. Dengan demikian apa yang disebut budaya hukum itu adalah tidak lain dari keseluruhan faktor yang menentukan bagaimana sistem hukum memperoleh tempatnya yang logis dalam kerangka budaya milik masyarakat umum. Sehingga secara singkat dapat dikatakan bahwa apa yang disebut budaya hukum ini adalah tidak lain dari keseluruhan sikap dari warga masyarakat dan sistem nilai-nilai yang ada dalam masyarakat yang akan menentukan bagaimana seharusnya hukum itu berlaku dalam masyarakat yang bersangkutan (F riedman M. Lawrence, $2002: 47$ ).

Dapat dikatakan bahwa, budaya hukum memiliki pengaruh yang cukup besar di dalam perkembangan sistem hukum di dalam masyarakat. Bagaimana hukum itu berlaku di dalam masyarakat akan ditentukan oleh sikap dan sistem nilai dari masyarakat yang berada dalam wilayah hukum tersebut. Kesadaran hukum yang ada di dalam suatu masyarakat dapat mempengaruhi berjalanannya sistem hukum di dalam masyarakat tersebut.

Budaya hukum dari suatu masyarakat di suatu daerah juga dapatmempengaruhi cara berpikir dari para pemegang wewenang perancang peraturan di daerah tersebut. Cara berpikir tersebut kemudian membentuk persepsi - persepsi yang tentu saja memiliki pengaruh terhadap proses pembentukan suatu peraturan di daerahnya. Diantaranya adalah persepsi tentang arti dari naskah akademik di dalam proses penyusunan suatu Raperda. Ada sebagian dari perancang peraturan di daerah yang memiliki pandangan bahwa penyertaan naskah akademik dalam penyusunan Raperda hanya akan memperlambat proses penyuasunan dari suatu produk hukum.

Penyusunan suatu peraturan perundang- 
undangan berlangsung dalam struktur sosial tertentu dan merupakan bagian dari proses sosial yang lebih besar, untuk itu penyusunan sebuah peraturan perundang-undangan tidak secara otomatis berjalan lancar, manakala struktur sosial dimana perbuatan itu berlangsung tidak demokratis atau sangat tergantung dari kondisi masyarakat (S irajuddin, dkk, 2007 : 183).

Adanya rasa kurang memiliki terhadap peraturan perundang - undangan dari masyarakat akhir - akhir ini, menjadi salah satu penyebab rendahnya kesadaran mereka untuk turut berpartisipasi dalam pembentukan sebuah pertauran perundang- undangan, khususnya Perda.Naskah akademik pada prinsipnya merupakan tuangan dari pertisipasi masyarakat dalam menyampaikan aspirasinya. Tanpa adanya kesadaran dar masyarakat untuk berpartisipasi dalam proses pembentukan sebuah Perda, secara tidak langsung akan menjadikan peranan serta penyertaan naskah akademik dalam suatu proses pembentukan perda menjadi kurang optimal.

\section{Implikasi Yuridis Terhadap Perda Kabupaten Mempawah, Kabupaten Kubu RayaDan Kota Pontianak Di Provinsi Kalimantan Barat Yang Kurang Mendayagunakan Naskah Akademik.}

Pada prinsipnya, secara yuridis normatif memang tidak ada implikasi langsung yang ditimbulkan dari tidak disertakannya naskah akademik dalam proses penyusunan suatu Perda. Karena memang pada dasarnya hal tersebut bukanlah sesuatu yang diharuskan. Dapat dikatakan bahwa tidak ada aturan yang secara langsung dilanggar oleh hal tersebut. Akan tetapi pada proses pembentukan dan perkembangan hukum di Indonesia saat ini, tidak disertakannya naskah akademik di dalam proses penyusunan suatu Perda kemudian dapat menjadi salah satu penyebab munculnya permasalahan dalam proses pembentukan produk hukum daerah. $\mathrm{Hal}$ tersebut kemudian mengakibatkan terganggunya tatanan sistem hukum yang sedang dibangun di Negara ini.

Dalam penyusunannya, subtansi dari sebuah Perda pada dasarnya harus dapat mencerminkan kondisi dan kebutuhan dari masyarakat di tiap daerah.Sehingga penerapan dari Perda tersebut nantinya dapat memberikan solusi kepada masalah yang benar - benar terjadi di daerah tersebut. Sebuah Perda yang telah ditetapkan walaupun sudah sesuai dengan peraturan perundang
- undangan yang lebih tinggi, tidak akan berjalan dengan baik jika subtansi yang ada di dalamnya tidak sesuai dengan kebutuhan dan kondisi masyarakat di daerah tersebut. Sehingga dapat mengurangi kemungkinan Perda yang akan dibentuk tersebut nantinya bertentangan dengan kepentingan umum.

Keikutsertaan masyarakat dalam pembuatan hukum diharapkan menjadi kekuatan kontrol (agent of social control) dan kekuatan penyeimbang antara kepentingan pemerintah dan masyarakat.Dengan dianutnya sistem politik yang demokrastis, kesempatan untuk berpartisipasi dalam pembentukan hukum lebih terbuka.Dalam pengertian ini, arena hukum menjadi semacam forum politik, dan partisipasi hukum mengandung dimensi politik. Dengan perkataan lain, aksi hukum merupakan wahana bagi kelompok atau organisasi untuk berperan serta dalam menentukan kebijaksanaan umum (Mulyana W. Kusumah, 1986 : 18). Partisipasi masyarakat dalam proses pembentukan Perda akan memberikan nilai tambah terhadap Perda yang akan dibentuk tersebut. Dengan adanya partisipasi dari masyarakat, para perancang peraturan di daerah dapat mendengar langsung serta mengetahui lebih jelas tentang apa hal yang sangat dibutuhkan masyarakat, sehingga dapat diprioritaskan dalam Perda yang akan disusun. Hal tersebut dapat dilakukan dengan cara menyertakan naskah akademik dalam setiap Perda yang akan dibentuk. Naskah akademik dapat dijadikan penghubung antara kepentingan politik dari perancang peraturan di daerah dengan masyarakt di daerah tersebut.

Pembentukan Perda yang pada subtansinya tidak mencerminkan kebutuhan dan kondisi masyarakat di daerah tersebut, berpeluang besar menimbulkan gejolak serta penolakan. Hal tersebut juga dapat menimbulkan turunnya rasa kepercayaan masyarakat kepada para pemegang wewenang serta perancang peraturan di daerah karena mereka tidak merasa memiliki terhadap peraturan - peraturan yang ada. Selain itu, jika suatu Perda dari Pemerintah Daerah Kabupaten dan Kota yang pada subtansinya bertentangan dengan peraturan perundang - undangan yang lebih tinggi serta pada penerapannya bertentangan dengan kepentingan umum dapat juga 
mengakibatkan dibatatalkannya Perda tersebut.Seperti yang diatur dalam Pasal 251 ayat (2) Undang - Undang Nomor 23 Tahun 2014 tentang Pemerintahan Daerah bahwa "Perda Kabupaten/Kota dan peraturan bupati/wali kota yang bertentangan dengan ketentuan peraturan perundangundangan yang lebih tinggi, kepentingan umum, dan/atau kesusilaan dibatalkan oleh gubernur sebagai wakil Pemerintah Pusat". Jika dalam penerapannya kemudian Gubernur yang dalam hal ini telah diberikan wewenang oleh Pemerintah Pusat tidak melakukan tugasnya untuk membatalkan Perda yang dimaksud, maka Pemerintahan Pusat akan mengambil alih untuk membatalkan Perda tersebut. Hal ini seperti yang telah diatur dalam Pasal 251 ayat (3) Undang - Undang Nomor 23 Tahun 2014 tentang Pemerintahan Daerah yang mengatur bahwa "Dalam hal gubernur sebagai wakil Pemerintah Pusat tidak membatalkan Perda Kabupaten/Kota dan/atau peraturan bupati/wali kota yang bertentangan dengan ketentuan peraturan perundang-undangan yang lebih tinggi, kepentingan umum, dan/atau kesusilaan sebagaimana dimaksud pada ayat (2), Menteri membatalkan Perda Kabupaten/Kota dan/atau peraturan bupati/wali kota".

Seperti yang telah disebutkan sebelumnya, hingga bulan J uni 2016 ada ribuan Perda yang sudah dibatalkan oleh Menteri Dalam Negeri.Pembatalan terhadap Perda - Perda tersebut dilakukan karena dianggap bertentangan dengan kepentingan umum atau bertentangan dengan peraturan perundang - undangan yang lebih tinggi. Dari ribuan Perda tersebut, ada beberapa di antaranya yang merupakan Perda dari Pemerintah Daerah Kota Pontianak, Kabupaten Mempawah dan Kabuaten Kubu Raya. Perda - Perda tersebut antara lain ialah :

Tabel 3.1

Perda Kota Pontianak yang Dibatalkan Oleh Pemerintah Pusat

Pada Tahun 2016

\begin{tabular}{|c|c|c|}
\hline No & J udul Perda & Nomor Perda \\
\hline 1 & Pajak Daerah & 1 Tahun 2011 \\
\hline 2 & Retribusi J asa Umum & 4 Tahun 2011 \\
\hline 3 & Pelayanan Publik Pemerintah & 2 Tahun 2010 \\
\hline 4 & Hutan Kota & 11 Tahun 2011 \\
\hline 5 & $\begin{array}{l}\text { Perubahan Atas Peraturan Daerah Nomor } \\
13 \text { Tahun } 2006 \text { Tentang Pengawasan, } \\
\text { Pengendalian, dan Pengusahaan Budi } \\
\text { Daya Burung Walet Daerah Kota Ponti- } \\
\text { anak }\end{array}$ & 9 Tahun 2011 \\
\hline 6 & $\begin{array}{l}\text { Perubahan Atas Perda Nomor } 6 \text { Tahun } \\
2004 \text { tentang Retribusi Izin Usaha J asa } \\
\text { Konstruksi }\end{array}$ & 8 Tahun 2009 \\
\hline
\end{tabular}

Sumber : Kementerian Dalam Negeri 
Tabel 3.2

Perda Kabupaten Mempawah yang Dibatalkan Oleh Pemerintah Pusat

Pada Tahun 2016

\begin{tabular}{|c|l|c|}
\hline No & Judul Perda & Nomor Perda \\
\hline & & \\
1 & Retribusi Terminal & 12 Tahun 2010 \\
2 & Retribusi Mendirikan Bangunan & 15 Tahun 2010 \\
3 & Retribusi Izin Gangguan & 16 Tahun 2010 \\
\hline
\end{tabular}

Sumber : Kementerian Dalam Negeri

Tabel 3.3

Perda Kabupaten Kubu Raya yang Dibatalkan Oleh Pemerintah Pusat

Pada Tahun 2016

\begin{tabular}{|c|l|c|}
\hline No & J udul Perda & Nomor Perda \\
\hline 1 & Pajak Daerah & 1 Tahun 2011 \\
2 & Retribusi Izin Mendirikan Bangunan & 1 Tahun 2010 \\
3 & Retribusi Izin Gangguan & 8 Tahun 2010 \\
3 & Retribusi Terminal & 18 Tahun 2010 \\
4 & Retribusi Rumah Potong Hewan & 13 Tahun 2010 \\
5 & Urusan Pemerintah yang Menjadi & 2 Tahun 2008 \\
& Urusan Pemerintahan Kabupaten & \\
6 & Kubu Raya & 3 Tahun 2011 \\
& Perubahan Atas Peraturan Daerah & \\
& Kabupaten Kubu Raya Nomor 2 Tahun & \\
& 2010 Retribusi Pengantian Biaya & \\
& Cetak Kartu Tanda Penduduk dan Akta & \\
\hline
\end{tabular}

Sumber : Kementerian Dalam Negeri

Menurut Koordinator Komite Pemantau Legislatif (Kopel) Indonesia Syamsuddin Alimsyah,mayoritas produk legislasi politisi DPRD dan pemda itu itu hanya untuk menggugurkan kewajiban. Bahkan cenderung alat untuk studi banding bagi pejabat, untuk mendapatkan uang perjalanan dinas. Bahkan ada banyak perda yang copy paste(Makassar tribun news, 2306 2016).

Dari gambaran tersebut, dapat dipaparkan efek yang mungkin ditimbulkan dari Perda yang penyusunannya tidak suatu perencanaan serata kajian yang baik tersebut, antara lain :

1. Perda tersebut pada subtansinya tidak sesuai dengan kebutuhan dan kondisi dari masyarakat di daerah tersebut, sehingga Perda tersebut kemudian tidak dapat menjawab masalah yang benar benar ada di dalam masyarakat;

2. Karena tidak sesuai, Perda tersebut sangat mungkin untuk tidak berlaku secara efektif, bahkan ada kemungkinan Perda tersebut kemudian menimbulkan gejolak di daerah serta tidak dipatuhi oleh masyarakat;

3. Ada kemungkinan Perda tersebut kemudian dibatalkan oleh Pemerintah Pusat.

4. Pembatalan Perda terebut dapat 
menimbulkan pengaruh kepada aspek hukum, ekonomi, sosial, maupun budaya yang cukup besar kepada Pemerintah Daerah serta masyarakat di daerah.

J ika ditarik garis besar dari munculnya Perda - Perda bermasalah tersebut, maka akan muncul sebuah gambaran tentang pentingnya suatu perencanaan yang baik di dalm proses penyusunannya. Dengan melakukan kajian yang mendalam berdasarkan kepada logika dan fakta yang ada di dalam masyarakatserta berlandaskan pada landasan yuridis, filosofis dan sosiologis yang kuatsebelum dibentuknya sebuah perda, maka kemungkinan besar permasalahan tersebut akan dapat diatasi.

\section{Simpulan}

1. Faktor-faktor yang kemudian menyebabkan pemerintah daerah Kota Pontianak, Kabupaten Mempawah dan Kabupaten Kubu Raya tidak menyertakan naskah akademik didalam setiap penyususnan $R$ aperda dalam Prolegda Tahun 2011, 2012, 2013, 2014 dan 2015 ialah :

a. Karena tidak diharuskannya penyertaan naskah akademik dalam penyusunan suatu Raperda di dalam Undang Undang Nomor 12 Tahun 2011 tentang Pembentukan Peraturan Perundang Undangan.

b. Kurangnya kompetensi tentang pemahaman pembentukan sebuah peraturan perundang-undangan yang baik yang disebabkan oleh beragamnya latar belakang yang dimiliki oleh para pemegang wewenang pembentuk peraturan khususnya pada tingkat legislatif.

c. Adanya rasa kurang memiliki terhadap peraturan perundang-undangan dari masyarakat akhir-akhir ini serta rendahnya kesadaran mereka untuk turut berpartisipasi dalam pembentukan sebuah pertauran perundang- undangan, khususnya Perda.

2. Pembentukan sebuah Perda yang pada penyusunannya tanpa melalui sebuah perencanaan yang baik serta mendalam ternyata dapat menimbulkan sebuah efek domino yang cukup berpengaruh kepada kondisi hukum yang ada di Indonesia. Mulai dari Perda yang subtansinya tidak sesuai dengan kebutuhan masyarakat di daerah, sehingga kemudian tidak dapat menjawab permasalahan yang ada di masyarakat serta tidak berlaku secara efektif. Hingga kemungkinan untuk dibatalkannya Perda tersebut oleh pemerintah pusat, karena dianggap bertentangan dengan kepentingan umum atau aturan diatasnya.

\section{E. Saran}

1. Pemerintah Derah Kabupaten Mempawah, Kabupaten Kubu Raya dan Kota Pontianak dapat lebih mempertimbangkan kembali tentang kedudukan naskah akademik dalam penyusunan suatu Perda serta memberikan ruang yang cukup bagi tenaga ahli atau akademisi yang merupakan ahli di bidangnya sebagai tenaga yang dapat membantu dalam proses pembentukan Perda

2. DPRD khususnya di daerah Kabupaten Mempawah, Kabupaten Kubu Raya dan Kota Pontianak dapat lebih aktif dalam merespon permasalahan - permasalahn yang ada di dalam masyarakat di daerah. Dapat lebih berpihak kepada kepentingan masyarakat, serta dapat lebih mengerti mengenai kebutuhan dari masyarakat. Serta dapat memberikan dorongan kepada masyarakat secara lebih baik untuk dapat berpartisipasi dalam proses pembentukan suatu Perda, agar masyarakat dapat lebih merasa memiliki terhadap Perda yang berlaku di daerahnya. 


\section{Daftar Pustaka}

\section{BUKU}

Adi Sulistiyono. 2002.Mengembangkan Paradigma Penyelesaian Sengketa Non-Litigasi Dalam Rangka Pendayagunaan Alternatif Penyelesaian Sengketa Bisnis/Hak Kekayaan Intelektual.Disertasi Doktor Ilmu Hukum UNDIP. Semarang.

Hamzah Halim dan Kemal Redindo S yahrul Putera, 2013, Cara Praktis Menyusun \& Merancang Iperaturan Daerah (Suatu Kajian Teoritis \& Praktis Disertai Manual), Konsepsi Teoritis Menuju Artikulasi Empiris, Cetakan ke-3, J akarta, Kencana Prenada Media Group.

Friedman M. Lawrence. 1969.On Legal Development. diterjemahkan oleh Rachmadi Djoko Soemadio. Rutgers Law R eview.

J azim Hamidi 2008.P embentukan Peraturan Daerah Partisipatif.J akarta. Penerbit P restasi Pustaka.

Mulyana W. Kusumah, 1986, Perspektif, Teori, dan Kebijaksanaan Hukum,J akarta, Rajawali.

Sirajuddin, dkk.2007,Legislative Drafting: Pelembagaan Metode Partisipatif dalam Pembentukan Peraturan Perundang-Undangan. Malang, In-TRANS Publishing.

Solichin Wahab, 2012, Masa Depan Otonomi Daerah (Kajian Sosial, E konomi, Politik,, Untuk Menciptakan Sinergi Dalam Pembangunan Daerah), Surabaya SIC.

Selayang Pandang DPR D Kota Pontianak, Masa J abatan 2014-2019.

Profil Dewan Perwakilan Rakyat Daerah Kabupaten Mempawah Masa Jabatan 2014-2019.

Profil Dewan Perwakilan Rakyat Daerah Kabupaten Kuburaya, Masa J abatan 2014-2019

J URNAL/MAKALAH

M Ilham F Putuhena, 2013, "P olitik Hukum Perundang - Undangan : Mempertegas R eformasi Legislasi Yang Progresif", J urnal Rechtsvinding, Volume 2 No 3.

Soetandyo Wignjosoebroto, Peneltian Hukum Sebuah Tipologi, dalam J urnalMasyarakat Indonesia, Tahun I No. 2, 1974.

Sony Maulana, 2005, Perancangan Peraturan Daerah Sebagai Wujud Kontribusi Keikutsertaan Pemerintah Daerah Dalam Perubahan Sosial Yang Demokratis Di Daerah, Makalah pada Bimbingan Teknis Harmonisasi Peraturan Daerah (Perda) Wilayah Perbatasan Dalam Perspektif Hak Asasi manusia, Samarinda.

\section{DATA INTER NET}

http://www.republika.co.id/berita/koran/opini-koran/16/06/15/08sws614-perdaperda-bermasalah diakses pada tanggal 25 September 2016

http://makassar.tribunnews.com/2016/06/23/biaya-1-perda-bisa-rp-2-m-tapi-banyak-juga-copy-paste diakses pada tanggal 25 September Pukul 17.38 WIB. 